2016

What Does Faith Got to Do with It? Influences on Preservice Teachers' Racial Identity Development

Yune Tran

Follow this and additional works at: https://digitalcommons.georgefox.edu/soe_faculty

Part of the Christianity Commons, Education Commons, and the Race and Ethnicity Commons 


\section{What Does Faith Got to Do with It? Influences on Preservice Teachers' Racial Identity Development}

Yune Tran

\begin{abstract}
The U.S. student population has grown more racially and culturally diverse demanding teachers who possess certain skills, competencies, and cross-cultural proficiencies to serve students equitably. With a continual homogeneous White teaching force, studies on preservice teachers' racial identity have prioritized in the field to promote anti-racist education within a social justice model. However, few studies have documented identities of preservice teachers who attend predominantly private evangelical Christian institutions. This mixed-method study investigated White preservice teachers' racial identity development focusing on the interconnectedness of religion with beliefs of race, culture, and diversity.
\end{abstract}

\section{KEYWORDS}

Identity; race; religion

The National Center for Education Statistics ${ }^{1}$ reported that almost half of the student population in the United States in 2008-2009 was non-White. Although the demographic reality in U.S. classrooms point to a growing number of culturally diverse students, the teaching force is still relatively homogeneous ${ }^{2}$ with the majority of teachers represented from White European American and middle-class backgrounds. ${ }^{3}$ Gay and Howard ${ }^{4}$ have argued that in addition to the less diverse teaching force, the "demographic divide" has created disparities in educational opportunities, resources, and achievement among student groups who differ in race, culture, and socioeconomic class. Furthermore, Darling-Hammond and Bransford ${ }^{5}$ noted that even though differences in race and language exist between teachers and students, there are also marked differences in their biographies and experiences. Most teachers do not have the same points of views ${ }^{6}$ or cultural frames of reference similar to their students. ${ }^{7}$

Unintentionally though, many White teachers reproduce racial inequities, ${ }^{8}$ which have led to significant research dedicated to preparing teachers with the tools and attitudes to implement culturally responsive classrooms and curricular practices. ${ }^{9,10}$ In developing cultural competence, scholars have argued that teachers need to first understand their own teaching beliefs ${ }^{11}$ and practices ${ }^{12}$ while reflecting on their own identity development to consider how these perspectives influence interactions with students. A study by 
Solomona, Portelli, Daniel, and Campbell ${ }^{13}$ revealed that White preservice teachers employed strategies of ideological incongruence, liberalist notions of individualism, and the negation of White capital when addressing Whiteness. As such, studies on White preservice teachers have addressed the benefits of antiracist coursework in teacher education programs ${ }^{14}$ designed to promote understanding of racial oppression in schools ${ }^{15}$ and for preservice teachers to conceptualize their own Whiteness. ${ }^{16}$ These studies are influential within the context of multicultural education; however, limited research exists to document White preservice teachers' racial development from private, evangelical Christian institutions and the role that they play when addressing attitudes and beliefs about cultural and linguistically diverse (CLD) students. Therefore, the purpose of this mixed-method research was to understand White preservice teachers' racial identity development and how they inform beliefs about race, culture, and CLD students. The research questions for the study were: (1) What racial identities exist for Christian White preservice teachers who attend a private evangelical institution? and (2) What beliefs do Christian White preservice teachers hold about themselves in regards to race, culture, and linguistically diverse students?

\section{Literature review}

Many teacher education programs have adopted social justice models that are committed to training preservice teachers to effectively work with all students. A framework of these programs support preservice teachers' deep content knowledge of historical factors that have marginalized certain groups and how those outcomes affect the achievement gap between White students and those of color. ${ }^{17}$ Teacher candidates also need to openly dialogue about race and racism, but the reality is that many distanced themselves from these topics due to discomfort and avoidance. ${ }^{18}$ In addition, White preservice teachers have avoided confronting notions of race or their own Whiteness. ${ }^{19}$ Some White teachers have also neglected that racism is prevalent in the country given the recent achievements by non-Whites in the United States. ${ }^{20,21}$ Thus, a longitudinal study by Gau and Mager ${ }^{22}$ found that teacher candidates are predisposed to maintaining negative beliefs about working with students of color in their coursework and preparation experience if critical discourse has not occurred to provide opportunity for them to examine their own biases in working with CLD students. Thus, many teachers are unaware of their own biases and misconceptions particularly for Latino and Black students resulting in lower academic expectations and a reliance on passive teaching methods. ${ }^{20}$

Furthermore, many scholars believed that teaching stems from within, asserting that teaching is based upon previous and current experiences. This body of knowledge argued that teachers either consciously or unconsciously reveal their identities to students by "teaching what they are." ${ }^{23}$ For example, 
a study on African American teachers by Irvine ${ }^{24}$ found that teachers categorized teaching from characteristics that have originated from their own racial and cultural backgrounds into a perspective that involved empathy, caring, mothering, and believing. As a result, African American students performed better in school when taught by African American teachers. This phenomenon, as explained by the author, is the idea of teaching within a cultural lens, a method that involves taking different perspectives among students and embracing diversity as an asset. ${ }^{24}$ Although much work has been done in the field to help teachers foster positive attitudes about racial diversity and sensitivity, most have focused on addressing content knowledge rather than using appropriate strategies around competent skills needed to work effectively with CLD students. ${ }^{25}$ It is critical, then, that White preservice teachers examine their racial beliefs before they can successfully work with students of color. ${ }^{26}$

\section{Racial identity development}

The role of understanding preservice teachers' racial identity development is essential in teacher education programs when promoting multicultural competence. $^{27}$ Several racial identity development theories have been developed including Helms ${ }^{28}$ original model of White racial identity (WRI) used to represent six statuses with higher levels indicating more advanced understanding of Whiteness and response to racism in the environment. Furthermore, Helms ${ }^{29}$ assumed that racism is an integral issue of WRI, fluid within a particular context, and characterized by different statuses from least developmentally mature to most developmentally mature. Helms eventually eliminated one of the statuses (immersion/emersion) yielding a model with the following five statuses: (1) contact (obliviousness to the presence of Whiteness, one's race, and racism; (2) disintegration (acknowledgement of racism, awareness of one's Whiteness, confusion with one's Whiteness, increased interactions with people of color, and recognition of systematic disadvantages that people of color have encountered; (3) reintegration (feelings of guilt, anger, and resentment toward people of color and idealization of being White; (4) pseudoindependence (acceptance of one's race, its privileges, and understanding how race is shaped around political, social, and economical implications; and (5) autonomy (effectively and positively internalizing a healthy antiracist White identity. Individuals at the lower end of WRI (i.e., contact, disintegration) are often unaware of associated privileges and deny institutional racism. By contrast, individuals at the higher end recognize the injustices that occur and are willing to take action for social justice given their advanced understanding of their own Whiteness. ${ }^{30}$ Reaching the final developmental phase is not an end point, but rather, a continuous recycle of prior statuses where one status may be dominant while others are operating. ${ }^{30}$ 
The longitudinal study by Haviland ${ }^{18}$ supported the need in learning about how White teachers approached issues of race and racism in Whitedominated educational settings that impede progressive movement to antiracist education. Her study found that White teachers engaged in certain behavioral and interactional strategies that insulate themselves from implications in social inequality. Thus, the "silencing power" of Whiteness displayed by the participants hindered attempts for transformational multicultural education that negatively reproduced the status quo of education and social inequality. ${ }^{18}$ Many Whites perpetuate their own privilege by avoiding discussions of race or espouse a "colorblindness" approach to negate the impact of racism on students of color. ${ }^{31}$ Other research has revealed that White teachers can show reluctance in communicating their feelings about race and racism due to a fear of appearing racist. ${ }^{32}$ These studies indicated that White teachers not only avoid discourse about race and racism but also may adopt a colorblind ideology that prevent their own healthy development of racial identities, and ultimately, negatively affecting their abilities in working with CLD students. Therefore, studying and facilitating WRI development seems appropriate to combat forms of racism within a social justice model of teacher education.

\section{Religion, culture, and teaching}

Membership in a particular religious group can influence one's identity, beliefs, and cultural patterns significantly. Shared religious beliefs rooted in a religious identity and practices have shaped cultural patterns of daily life; thus, for communities with shared ideologies, religious identity becomes a salient function of culture translated into rituals, routines, and practices. ${ }^{33}$ Measuring religious and mental functioning for group affiliation has been limited to a broad range of tests based on categorical variables such as affiliation, attendance, and orthodoxy. ${ }^{34}$ Studies of religion became focused on two factors: motivation (intrinsic vs. extrinsic) and how beliefs are held (quest vs. fundamentalism).$^{35}$ Psychologists of religion have described the differences in motivation by specifying that intrinsically motivated individuals possess true commitments to their religion with "faith as a supreme value in its own right ... oriented to a unification of being that takes seriously the commandment of brotherhood, strives to transcend all self-centered needs" (455). ${ }^{36}$ In contrast, extrinsically motivated individuals practice religion that is "strictly utilitarian; useful for the self in granting safety, social standing, solace, and endorsement of one's chosen way of life" (455). ${ }^{36}$ Recent expansions in the study between religion and psychology included (1) fundamentalism relating to one particular set of religious teachings that outline basic and essential truths on humanity and deity ${ }^{37}$ and (2) quest relating to the openness, doubt, and resistance to simple questions about religion. ${ }^{38}$ 
Although some research exists between human development and religion, it has been inconsistent. And surprisingly, the impact of religion on educational practices has been neglected in the literature ${ }^{39}$ with scholars arguing for further investigation of this phenomenon. ${ }^{40}$ Burke and corresponding authors ${ }^{41}$ have emphasized exploration between the connection of human development (i.e., cognitive, psychosocial, moral, etc.) and spiritual/religious beliefs given the difficulty of separating teachers' personal and professional identities. ${ }^{42,43}$ Thus, merging identities of religion and teaching have translated into the classroom space for justifications of effective pedagogies and practices. $^{42,44}$

Although there are various approaches to religion and spirituality, these terms are used interchangeably. The connection between the terms provides an understanding how preservice teachers' personal faith play in shaping their identities, priorities, relationships, and overall experience in the preparation program. ${ }^{45,46}$ According to Richards and Bergin ${ }^{34}$ spirituality is defined as "experiences, beliefs, and phenomena that pertain to the transcendent and existential aspects of life" (13) whereas religion is described as "theistic beliefs, practices, and feelings that are often but not always, expressed institutionally and denominationally as well as personally" (13). The education field has attracted a number of religious students, ${ }^{47}$ many who feel that God has called them to the profession. ${ }^{48}$ Understanding this calling through teachers' stories can reveal the portrayal of theoretical notions through a religious and spiritual experience ${ }^{44,49}$ that translate into knowing and becoming a teacher.

\section{Research context}

Given the potential interconnectedness of race and religion in the process of teacher development, there is a need for research to examine the relationship of these dimensions. Participants for this study were undergraduate students enrolled at a liberal-arts Christian institution located in the Pacific Northwest. At the time of the study, the student population consisted of 2,384 undergraduates identified as $78.8 \%$ White, $57.4 \%$ females, $42.6 \%$ males, and $86.4 \%$ Christian (encompassing a variety of faith backgrounds such as nondenomination, Roman Catholic, Baptist, Methodist, Orthodox, etc.). Explicit mission of the university emphasizes an evangelical Christian standpoint to prepare students spiritually, academically, and professionally placing these core values: (1) students first, (2) Christ in everything, and (3) innovation to improve outcomes. The university's Quaker heritage also includes a commitment for social justice, peace and nonviolence, and the practice of equality for all people. The research focus was on 38 preservice teachers matriculated at the university in an education foundations course during the fall and spring semesters of the 2013-2014 academic year. Informed consent was obtained during a face-to-face recruitment meeting in the third week of the course 
for each fall and spring semester respectively. Participants completed the consent form and the revised White Racial Consciousness Development Scale (WRCDS-R) that aligned to Helms ${ }^{28}$ theory of WRI development. ${ }^{50}$ The WRCDS-R instrument revealed satisfactory reliability using Cronbach's alpha coefficients and consisted of 40 five-point likert scale item $(1=$ strongly disagree; $5=$ strongly agree) to reflect the four WRI statuses for contact (.81), reintegration (.86), pseudoindependence (.84), and autonomy (.71).

\section{Data sources and analysis}

A mixed method case study approach was used for the research design. ${ }^{51}$ Of the 33 surveys returned (a retrieval rate of $86 \%, 3$ males, 30 females), all participants self-identified as ethnically White, religiously Christian, between 18-20 years old, and representative of the larger student population enrolled in the teacher education program. Eight preservice teachers (seven female, one male) voluntarily provided their names for qualitative data collection that included individual interviews and written personal development narratives over the fall and spring semester. A brief profile of these cases based on participants' own summaries are provided in Table 1. Participants (Heather, Nancy, Cindy, Tiffany, Amy, Samantha, Emily, and James-all pseudonyms-submitted a summary of their journal notes used as a tool for guided reflection ${ }^{52}$ in the form of a narrative paper by providing accounts of their upbringing; views of culture, race, diversity; and peer relationships. Data from WRCDS-R surveys were imported into STATA and NVIVO software to support analysis. Mean scores from survey responses were collected and analyzed to reveal the lowest and highest self-rated items and grouped according to the four statuses. Paired samples $t$-tests and analysis of covariance were employed but no correlations were found given the similarity of participants' backgrounds, gender, age, and religious affiliations. Other limitations included the small nonlongitudinal sample and the inability to cross compare groups from similar faith-based institutions or with student groups majoring in different disciplines. Individual interviews were taped recorded and transcribed producing roughly 25 singlespaced pages of text. Interview data and participants' personal narratives were imported to NVIVO software. Miles and Hubernaman's ${ }^{53}$ approach along with narrative inquiry analysis ${ }^{54}$ were used for patterns and themes across individual responses. Although individual responses varied, emerging salient themes were categorized into commonalities among participants' responses that generated group-centered results rather than individualistic notions.

\section{Findings}

Self-reported quantitative scores, personal narratives, and interviews were combined to inform the researcher's understanding of salient themes. 
Table 1. Profile of participants' backgrounds.

\begin{tabular}{|c|c|c|c|c|c|}
\hline Name & Helm's status & Family context & Home town & K-12 Culture & $\begin{array}{l}\text { Religious background (self- } \\
\text { identified) }\end{array}$ \\
\hline Heather & Disintegration & $\begin{array}{l}\text { Traditional, has one sister, } \\
\text { stay-at-home mom who } \\
\text { was very involved }\end{array}$ & $\begin{array}{l}\text { Rural, small town in } \\
\text { Washington }\end{array}$ & $\begin{array}{l}\text { Attended public school; } \\
\text { predominantly White; } \\
\text { some students from Spain, } \\
\text { Russia \& Ukraine }\end{array}$ & $\begin{array}{l}\text { Supportive \& raised in a } \\
\text { strong Christian home }\end{array}$ \\
\hline Nancy & Contact & $\begin{array}{l}\text { Traditional, only child, } \\
\text { parents still married, close } \\
\text { with parents }\end{array}$ & $\begin{array}{l}\text { Suburb, Northern } \\
\text { California }\end{array}$ & $\begin{array}{l}\text { Attended public school with } \\
\text { same peer group across K- } \\
\text { 12; predominantly White } \\
\text { with some ethnic students } \\
\text { in high school mainly } \\
\text { Latino and African } \\
\text { American }\end{array}$ & $\begin{array}{l}\text { Raised in a Christian } \\
\text { upbringing }\end{array}$ \\
\hline Cindy & $\begin{array}{l}\text { Contact, } \\
\text { developing into } \\
\text { disintegration }\end{array}$ & $\begin{array}{l}\text { Traditional, one of } 3 \\
\text { children, close-knit family, } \\
\text { parents still married }\end{array}$ & $\begin{array}{l}\text { Suburb, Northern } \\
\text { California }\end{array}$ & $\begin{array}{l}\text { Home-schooled K-8; } \\
\text { attended all White small } \\
\text { private Christian high } \\
\text { school }\end{array}$ & $\begin{array}{l}\text { Christian; attended } \\
\text { Christian private high } \\
\text { school }\end{array}$ \\
\hline Tiffany & $\begin{array}{l}\text { Pseudo- } \\
\text { independence }\end{array}$ & Traditional, close-knit home & Rural small town in Idaho & $\begin{array}{l}\text { Attended public school that } \\
\text { was mostly Caucasian and } \\
\text { some Latino students }\end{array}$ & $\begin{array}{l}\text { Strong Christian } \\
\text { upbringing; experiences } \\
\text { with international } \\
\text { missionaries }\end{array}$ \\
\hline Amy & Contact & $\begin{array}{l}\text { Traditional, close-knit home, } \\
\text { considers parents to } \\
\text { extremely involved in } \\
\text { school }\end{array}$ & $\begin{array}{l}\text { Suburb, northern } \\
\text { California then moved } \\
\text { to urban setting in } \\
\text { Washington }\end{array}$ & $\begin{array}{l}\text { Attended public school rated } \\
\text { well by local district and } \\
\text { community; transitioned } \\
\text { to large urban high school } \\
\text { with groups of ethnically } \\
\text { diverse students } \\
\text { represented }\end{array}$ & $\begin{array}{l}\text { Raised in supportive } \\
\text { Christian home }\end{array}$ \\
\hline Samantha & Contact & $\begin{array}{l}\text { Immigrant family from } \\
\text { Moldova, moved to U.S. in } \\
\text { 1st grade, close network } \\
\text { of family members }\end{array}$ & Suburb, Oregon & $\begin{array}{l}\text { Attended public school with } \\
\text { some ethnic diversity }\end{array}$ & $\begin{array}{l}\text { Non-denominational } \\
\text { Christian home }\end{array}$ \\
\hline
\end{tabular}


Table 1. Continued.

\begin{tabular}{|c|c|c|c|c|c|}
\hline Name & Helm's status & Family context & Home town & K-12 Culture & $\begin{array}{c}\text { Religious background (self- } \\
\text { identified) }\end{array}$ \\
\hline Emily & $\begin{array}{l}\text { Contact; } \\
\text { developing into } \\
\text { disintegration }\end{array}$ & $\begin{array}{l}\text { Traditional, close-knit family, } \\
\text { strong parental influence }\end{array}$ & Suburb, Washington & $\begin{array}{l}\text { Attended public school } \\
\text { predominantly } \\
\text { homogeneous with } \\
\text { limited contact from } \\
\text { students outside racial } \\
\text { group }\end{array}$ & $\begin{array}{l}\text { Christian home, Christ at } \\
\text { center and relationship } \\
\text { with Jesus deepened in } \\
\text { high school }\end{array}$ \\
\hline James & Contact & $\begin{array}{l}\text { Has one sister, parents } \\
\text { divorced in high school; } \\
\text { still close to both parents }\end{array}$ & Urban, Oregon & $\begin{array}{l}\text { Attended public school; } \\
\text { ethnic diversity was } \\
\text { evident; many languages } \\
\text { spoken }\end{array}$ & $\begin{array}{l}\text { Puts faith first, God in } \\
\text { everything }\end{array}$ \\
\hline
\end{tabular}


Table 2 indicates the mean, median, and mode scores with responses grouped along the levels of WRCD-R instrument: (1) contact, (2) reintegration, (3) pseudoindependence, and (4) autonomy. Results indicated preservice teachers' racial identities existed within contact status given higher mean averages on the survey that ranged from 3.33 as the lowest to 4.45 as the highest from a 5-point rating scale. Autonomy status received comparative high scores with contact status; nonetheless, data from interviews and narrative papers augmented survey responses to further support participants' characteristics aligned mostly with contact status while other statuses were developing. Of the eight cases who reached the different statuses, there were six in contact, one in disintegration, none in reintegration, one in pseudoindependence, and none in autonomy. After collapsing and merging descriptive codes with qualitative data (interviews, journals, and personal narratives) three themes emerged predominantly with cases: (1) interaction of family context/Christian perspective on teachers' identity; (2) limited interactions with persons of color; and (3) Christian environment can influence racial identity development.

\section{Theme 1: Interaction of family context/Christian perspective on teachers' identity}

Evidence in the study pointed to a strong relationship between participants' family context, Christian faith, and their identities. Study participants associated strongly with the Christian faith to provide a premise for understanding their family background, values, and cultural beliefs. Parents had been incredibly influential in participants' faith development. One participant, James, remarked how they have become deeply rooted in his faith, saying "My parents helped me understand that God has really opened my eyes to the call to love everybody and not base it on anything at all." Cindy supported this perspective to reference how her faith has influenced her upbringing, and primarily, the core of her lived experience. Cindy articulated this point saying,

My faith is also a defining point of who I am, maybe the strongest one. I was raised in a Christian family and accepted Christ as my savior at a very early age. My life has been rife with church activities. I am now at a private Christian university so my faith has been in every aspect of my life. I feel that much of my worldview comes from my faith. I can't really separate much of my thinking from that Christian base that I have.

For Cindy, whose faith was espoused early in life from a strong-knit family with close ties to the church, religion has contributed much to her knowledge of the world. Dimensions of her upbringing included conversations about religion in the home, daily religious practices (i.e., family prayer in the evening, grace at meals), frequent attendance at church, and service in the community. These aspects of James and Cindy's perspective in faith integration are echoed 
Table 2. Responses from White Racial Conscious Scale $(N=33)$, ranging from 1 (strongly disagree) to 5 (strongly agree).

\begin{tabular}{|c|c|c|c|}
\hline Question item & $M$ & Median & Mode \\
\hline \multicolumn{4}{|l|}{ Contact items } \\
\hline $\begin{array}{l}\text { I have had little contact with Black } \\
\text { people other than seeing them on } \\
\text { campus.* }\end{array}$ & 4.24 & 5 & 5 \\
\hline $\begin{array}{l}\text { I greatly enjoy cross-racial (involving } \\
\text { Blacks and Whites together) activities } \\
\text { and I try to participate in them often. }\end{array}$ & 4.33 & 5 & 5 \\
\hline $\begin{array}{l}\text { I have lived in close proximity to black } \\
\text { people. }\end{array}$ & 3.33 & 3 & 3 \\
\hline I have Black friends. & 4.45 & 5 & 5 \\
\hline $\begin{array}{l}\text { I have never had much contact with Black } \\
\text { people.* }\end{array}$ & 3.96 & 5 & 5 \\
\hline $\begin{array}{l}\text { I would feel uncomfortable living near } \\
\text { Black people. }\end{array}$ & 3.84 & 5 & 5 \\
\hline I do not have any Black friends.* & 4.39 & 5 & 5 \\
\hline $\begin{array}{l}\text { I feel comfortable when I am in close } \\
\text { contact with Black people. }\end{array}$ & 3.75 & 5 & 5 \\
\hline \multicolumn{4}{|l|}{ Reintegration items } \\
\hline $\begin{array}{l}\text { Blacks should not be allowed to continue } \\
\text { in school unless at same level as } \\
\text { Whites.* }\end{array}$ & 4.75 & 5 & 5 \\
\hline $\begin{array}{l}\text { Reversed discrimination is a big problem } \\
\text { for Whites in America. }\end{array}$ & 2.66 & 3 & 3 \\
\hline $\begin{array}{l}\text { I do not understand why Blacks are so } \\
\text { resentful of White people.* }\end{array}$ & 4 & 5 & 5 \\
\hline $\begin{array}{l}\text { I am afraid that minorities are taking over } \\
\text { American society. }\end{array}$ & 1.96 & 2 & 2 \\
\hline $\begin{array}{l}\text { Black people have brought many of their } \\
\text { problems on themselves. }\end{array}$ & 1.42 & 1 & 1.5 \\
\hline $\begin{array}{l}\text { Black people are responsible for their lot } \\
\text { in life. }\end{array}$ & 3.12 & 5 & 4 \\
\hline $\begin{array}{l}\text { Slavery stopped long ago, so Black } \\
\text { people should get over it. }\end{array}$ & 2.06 & 1 & 2 \\
\hline $\begin{array}{l}\text { Racism continues because Black people } \\
\text { dwell on the past. }\end{array}$ & 1.90 & 3 & 2 \\
\hline $\begin{array}{l}\text { In America, people pretty much decide } \\
\text { their own fate. }\end{array}$ & 3.54 & 4 & 4 \\
\hline $\begin{array}{l}\text { If Black people weren't so lazy, they } \\
\text { wouldn't be in the position they're in.* }\end{array}$ & 4.78 & 5 & 5 \\
\hline $\begin{array}{l}\text { There are more Black people on welfare } \\
\text { than Whites. }\end{array}$ & 2.75 & 3 & 3 \\
\hline $\begin{array}{l}\text { Affirmative action is just reverse } \\
\text { discrimination. }\end{array}$ & 3.06 & 3 & 3 \\
\hline $\begin{array}{l}\text { If Black people wanted to change things, } \\
\text { they could take action themselves. }\end{array}$ & 2.87 & 4 & 3.5 \\
\hline $\begin{array}{l}\text { Blacks must get over the issue of slavery } \\
\text { so that we can move on. }\end{array}$ & 2.15 & 3 & 3 \\
\hline \multicolumn{4}{|l|}{ Pseudo independence items } \\
\hline $\begin{array}{l}\text { White people think they are better } \\
\text { because of their skin color. }\end{array}$ & 2.18 & 1 & 2 \\
\hline $\begin{array}{l}\text { I support the idea of restitution for Blacks } \\
\text { based on the history of slavery and } \\
\text { oppression. }\end{array}$ & 3 & 4 & 3 \\
\hline $\begin{array}{l}\text { Dominance over others is a characteristic } \\
\text { of White culture. }\end{array}$ & 2.90 & 4 & 3 \\
\hline
\end{tabular}


Table 2. Continued.

\begin{tabular}{|c|c|c|c|}
\hline Question item & $M$ & Median & Mode \\
\hline $\begin{array}{l}\text { White people should provide some form } \\
\text { of restitution to Black people. }\end{array}$ & 2.66 & 3 & 3 \\
\hline $\begin{array}{l}\text { Throughout history, White people have } \\
\text { been the dominant oppressor. }\end{array}$ & 3.51 & 4 & 4 \\
\hline $\begin{array}{l}\text { If the media portrayed Black people more } \\
\text { positively, racial tensions would end. }\end{array}$ & 2.63 & 1 & 1 \\
\hline $\begin{array}{l}\text { White people are responsible for putting } \\
\text { an end to racism. }\end{array}$ & 2.48 & 2 & 2 \\
\hline $\begin{array}{l}\text { I am ashamed of what my Whiteness } \\
\text { represents. }\end{array}$ & 2.51 & 1 & 2.5 \\
\hline $\begin{array}{l}\text { I think White people should work hard to } \\
\text { give up their advantages. }\end{array}$ & 2.06 & 3 & 2.5 \\
\hline \multicolumn{4}{|l|}{ Autonomy items } \\
\hline $\begin{array}{l}\text { Whenever I witness it, I confront people } \\
\text { who make racist comments. }\end{array}$ & 3.60 & 4 & 4 \\
\hline $\begin{array}{l}\text { As a White person, I feel it is my } \\
\text { responsibility to help eradicate racism } \\
\text { and discrimination in our society. }\end{array}$ & 3.51 & 4 & 4 \\
\hline $\begin{array}{l}\text { My family would disown me if I married a } \\
\text { Black person.* }\end{array}$ & 4.75 & 5 & 5 \\
\hline $\begin{array}{l}\text { I would feel comfortable dating a Black } \\
\text { person. }\end{array}$ & 4.24 & 5 & 5 \\
\hline $\begin{array}{l}\text { My family would support me if I married } \\
\text { a Black person. }\end{array}$ & 4.33 & 5 & 5 \\
\hline $\begin{array}{l}\text { None of my friends would look down on } \\
\text { me for having an interracial } \\
\text { relationship. }\end{array}$ & 4.30 & 5 & 5 \\
\hline $\begin{array}{l}\text { When I hear a racist joke, I say something } \\
\text { to show my disapproval. }\end{array}$ & 3.45 & 3 & 3 \\
\hline $\begin{array}{l}\text { I would feel comfortable with a Black } \\
\text { physician. }\end{array}$ & 4.33 & 5 & 5 \\
\hline $\begin{array}{l}\text { When I hear someone make racist } \\
\text { comments, I say something to show my } \\
\text { disapproval. }\end{array}$ & 3.66 & 4 & 4 \\
\hline
\end{tabular}

Note: *Items with reversed scoring.

by Tiffany's own reflections of religious ministry work shaped her philosophy of teaching by embracing student's differences and creating a platform for success in their own endeavors. Tiffany responded saying,

I grew up in a strong Christian family with a love for God's word and His people. My love for God, His word, and His people sparked a passion for missions ... As my classmates and I discussed our future plans, I often felt as though people looked down on me or judged me for not only my plans to be a missionary, but also in my Christian faith. This experience of disapproval from my peers and others within my community has proven to be beneficial to me in the way of my future teaching. With this learning experience as a reminder, I can encourage my students to reach for their goals and not to be discouraged by those around them who may disagree with their goals.

James, Cindy, and Tiffany referred to a sense of existence that draws them to a connection extending beyond their own egos. They attributed their sense 
of identity from family ties and religious backgrounds that profoundly affected their values, interactions, knowledge, and perspectives of students in future classrooms. Emily reminisced this theme disclosing,

Being raised in a Christian home and associating myself with the Christian community has really affected and shaped my identity, as well. I am a follower of Jesus Christ and as such my whole being and identity is rooted in that relationship and belief in God ... My interactions with people and my attitudes towards things I do not agree with have changed through my "Christian lens." My political, educational, and ethical standpoints are influenced by my Christian faith. I believe my identity as a follower of Jesus Christ will positively impact my teaching and ultimately impact the children I teach. If I view every student as Jesus sees them, there will be no lost cause, no unworthy student, no hopeless case, no unintelligent student and no student unloved in my classroom. These may be high and lofty expectations I have set for myself but "I can do all things through Christ who strengthens me."

Emily, influenced heavily by her parents, alluded to how those strong relationships shaped her faith and understanding of the world. Her identity comes from a family upbringing where religion provided a base so that perspective can be derived from teachings of Christ. Perceptions shared by these preservice teachers reveal the intersections of family, religious, and spiritual formation in shaping the identities of James, Cindy, Tiffany, and Emily in their future calling as teachers. Nonetheless, these narratives show a glimpse how four preservice teachers embraced their Christian upbringing, identity, and practices when considering future interactions with students in terms of openness, fairness, and compassion similar to God's mercy and love for them.

\section{Theme 2: Limited interactions with persons of color}

While the racial composition of $\mathrm{K}-12$ schools have become more diverse, the cases profiled continually echo previous notions that U.S. teachers still come from European American middle-class backgrounds who only speak English with limited interactions with students from racial and ethnic minorities.... These experiences create conditions that prevent teachers from understanding students' cultural backgrounds given differences between race, language, and biographies. ${ }^{5}$ Without explicit attention to the perspective and varied interactions, there is a sense among individuals to approach color-blind ideologies and treat people the same. ${ }^{55}$ In the case of Heather, who grew up in a rural community, she described challenges of not being able to comfortably dialogue about issues of race in her home and the teachings of sameness for all. Heather commented,

My family rarely talked about different culture or ethnicities at home. The topic of race rarely came up and if it did my parents usually just told us to love everyone and moved on. I think this really influenced my abilities to talk about race or cultural 
differences and for a long time I struggled with addressing this topic openly. The school district in which I attended kindergarten through twelfth grade was fairly racially homogenous... Driving our Russian neighbor to school (several times) helped me to learn about the food eaten a specific meals and cultural expectations regarding religion and family life.

Heather's recollections of these challenges speak to individuals' understandings of difference referring to several Russian students as the means of interaction with people from a different background. James with limited diversity experiences said,

Most of my experience has been with kids, working at different Bible Club, which is one of the ministries that are in my church. Growing up I didn't have a whole lot of interaction with people of different races or ethnicities. It was just a little bit.

In addition, other preservice teachers credited their knowledge of diversity within $\mathrm{K}-12$ formative education years, which they perceived as contributing significantly in shaping their relationships with people of color. Tiffany replied,

When I was six and a half my family and I moved from Sunrise (pseudonym) to a small town in Idaho. This move played a large role in my experiences with diversity in society. If I were to have stayed in Sacramento I would have had more experience with diversity and different cultures were as in Challis most everyone was of the same race and ethnicity. There was little to no diversity within my high school with a majority of Caucasians and minority of Hispanic.

Another preservice teacher, Emily discussed that while being somewhat exposed to diversity, ethnic groups generally associate together articulating,

I never have had any really close friends that were of different races because there are just a lot of white people in Pineville (pseudonym). Also when you have different cultural barriers, you don't have that opportunity because all of my best friends have been white and I've dated someone that's white. I mean I love hanging out and meeting new people but you get stuck in your friends group and you don't need to reach out.

The above remarks represented Emily's personal decision and comfort with people who share similar cultural frames of reference. These frames of references limit individuals' understanding and appreciation for diversity, thus, inhibiting the development of cultural competency. ${ }^{54}$ Finally, Cindy described her lack of interactions with different cultures as an eye-opening realization saying,

When I came to Fox, I was immediately more aware of how much I didn't know about other cultures. If I was being completely honest, I had never had a true relationship with someone from another culture. Sure, I had spoken with a few Latino people and my dad knew a couple African American women at his work, but I never really knew someone from a culture different than my own. I went through my first semester pretty much the same way. I still didn't really know any multicultural students. 
Apparent in the voice of Cindy was the expectation in college to fulfill an assignment of interacting with an international student as part the course requirements. The weekly encounters with the international student eventually developed into a long-lasting friendship allowing Cindy to widen her perspective to other cultures in a more positive way.

\section{Theme 3: Christian environment can influence racial identity development}

Given the role of religion as a significant influence in shaping identity, it may be helpful to understand how the contextual factors around faith and religion can contribute to the one's formation. Thus, the final theme illuminates how a shared Christian environment shaped candidates' racial identify development. For Heather, who did not have significant experience with dialogue on racial issues growing up referenced how college fostered conversations about race that eventually allowed her to dispel misconceptions. This allowed her to gain confidence to share her thoughts in class, and ultimately, led to constructive understanding of her own racial development. She said,

Before coming to college I had only discussed and evaluated culture within society, and it took a safe environment and a push from my teacher to overcome my fears about race and ethnicity and become a more loving person. When I first came to Adams Christian University (pseudonym), I was afraid to talk at all about race. In school before this, race and ethnicity had always been fairly taboo topics that teachers and students alike avoided, and now that I was at college I was terrified to say anything for fear that I would offend someone. I thought that my ideas about equality were incorrect and that I would just embarrass myself by revealing how little I knew about race in general. However, as we began to discuss issues of racial inequality and as my fellow students opened up and shared their stories with me about their own experiences I began to solidify my opinions. The push from my teachers to share, to discuss, and to talk about these issues that I had previously never spoken brought me out of my comfort zone but helped me grow as an individual. I soon felt little to no fear when talking about race and ethnicity. The stories I heard about racism my friends had experienced and the stereotypes I encountered deeply touched my heart and moved me to become more open about the fallacies people were spreading and the damage students were inflicting upon each other. I learned that I do not have to walk on eggshells but can share my opinions respectively and help others to find clarity about issues regarding inequality. When everyone is afraid to speak, there can be no action and no love for others but when one looks at people as individuals and strives to love everyone, there is not fear of saying the wrong thing.

The above example represented the influence of the Christian community on students' knowledge of race and culture. Faculty members from the institution were expected to integrate faith into teaching with an ability to challenge students' thoughts about race in course discussions creating a space for students to negotiate about these prevalent issues. Thus, the classroom 
space allowed Heather to openly dialogue about race helping her to develop into disintegration status by recognizing the systematic disadvantages of her peers and people of color. In the case of Tiffany, who strategically chose to attend the Christian-based institution reflected in her journal on the college opportunity that allowed her to continue participation with missionaries. She commented,

However, when the time came to apply for colleges, my classmates and I discussed are future plans after high school I often felt as though people looked down on me or judged me for my plans to be a missionary, but also in my Christian faith. Once I moved for college, I was more exposed to diversity, but found the biggest impact in this area of my life to be when I went on a mission trip to Haiti in the spring of 2011. This experience will benefit me greatly in my potential teaching career because it has given me a greater understanding of what my ELL [English language learner] students may go through. I believe that by going through this cross-cultural experience I can begin to understand how I might be able to help my ELL students learn and interact within my classroom. Along with learning about racial differences I now have a better understanding of why they often noticed the difference.

The college environment fostered healthy interracial interactions for Tiffany but also promoted exposure to additional Christian missionary activities to understand her calling for teaching. Thus, this transformative experience allowed her to internalize the notion of how race is rooted around political and economic contexts. During the semester of the research, additional encounters with Tiffany frequently involved discussions of her experience with locals in Haiti who profoundly affecting her abilities to witnessing her own White privilege, associated benefits, while working to negotiate and challenge them.

Emily also shared Tiffany's sentiment expressing how her experiences at the university allowed her to critically examine her own biases while gaining a greater understanding on particular needs for culturally diverse students. She emphasized this point saying,

I am enrolled in the education ESOL [English speakers of other languages] program at Adams Christian University, which has given me a greater respect and understanding for ELLs in the classroom. Additionally, I have been learning skills and methods that will support ELL's acclimation and growth in a classroom environment... Every culture has a different perspective on what is important and what is not. Academically referred to as collectivist vs. individualistic cultures, each emphasis creates a different type of student ... Knowing this information will be very valuable when I am working with children from Chinese or Hispanic backgrounds. Although there are always variances, is it important to realize that students from other cultures have a different view of the classroom and what is to be expected of them. Because I am from a highly individualistic culture, I need to make sure that I do not make the mistake of assuming my Latino students are not responding to me because they are rude or unintelligent. My time at college has been very influential in maturing my identity as a Christian, as an American, as 
a leader, as a woman and as a teacher. The more time I spend here at Adams Christian University, the more I learn about myself and what gifts I can bring to the classroom. I am an individual; as such, my unique background and experiences will affect and influence my teaching style. Additionally being aware of my student's varying backgrounds will be a crucial element in promoting their educational growth.

Emily's remarks revealed the changes that occurred during college with intersections of faith and identity to nurture her racial development and affirmations on the gifts that culturally diverse students will bring to her future classroom. Cindy further emphasized the benefits in the network of a Christian community, which nurtured a deeper understanding and humility of her own culture saying,

The opportunity to have here at Adams Christian University has been extremely valuable to me. They (faculty) have helped me see that differences are okay, that we can still get along even if we see things differently, and that maybe my culture has downfalls.

Finally, the case of James revealed how college courses that embed discourse on race and social justice has raised his consciousness for appreciating others' backgrounds, perspectives, and values within a Christian lens. He specified this point saying,

Growing up, I was pretty racist especially with the whole illegal immigrants and taking this class and a couple other classes here (Adams Christian University) really opened up my eyes to seeing how it's not right and we should be sticking up for people and not discriminating on things just like that. I think my faith at Adams Christian University and doing classes that focus on diversity and treating all of our students equally have the same affect... I think the biggest thing would be overcoming fear of preconceived notions ... it doesn't matter where students are from, but at the same time, they have just as much right and ability as anyone else.

\section{Discussion}

Teacher education programs often promote engagement of White teachers into discussions of race issues in courses to confront the phenomenon of teachers' lack of knowledge with people of color. Previous studies have found that detrimental effects for White teachers with upbringings in homogenous and segregated communities exist that perpetuate into avoidance procedures to talk about race or racial issues in efforts to not appear racist. ${ }^{56}$ Although this argument underlies in the existing literature discussing White teachers' avoidance strategies including the cases profiled in this study, teacher education programs are raising consciousness about the differences between avoidance and resistance of racial issues. Some teacher educators have also transformed their classroom practices as evident in the study with course 
assignments to help White teachers understand the problematic premise of purposeful separation translated into lived experiences of limited interactions of people of color. Using the attributions of lack of knowledge on race due to limited exposure may actually lead to preservice teachers' inabilities to recognize the varied contributions in people of color and denying future CLD students valuable learning opportunities to respect, acknowledge, and celebrate difference.

The cases of Heather, Emily, Tiffany, Cindy, and James echoed similar implications of the preservice teachers whose lived experiences resemble that of White American suburbia with limited opportunities to engage with those different than themselves. Exposure to diverse experiences with peer groups, course assignments, or environmental considerations in college opened up conversations about race that were often avoided during their formative years in school. These preservice teachers became more comfortable in the discourse of race within a Christian perspective and gained appropriate tools and mechanisms to dialogue with respect and appreciation for people of color. This supported previous studies highlighting White teachers who likely possessed some understanding of race but were suppressed in formative years under the assumed view that White students simply lacked knowledge about race. ${ }^{57,58}$

Although there is truth in lack of experience that hinders understanding, it may be also true that the faith-based environment chosen by these White preservice teachers promoted an easier pathway of discourse on racial issues given common religious beliefs and values. The institution's Quaker heritage with priorities in religious and spiritual formation of their students likely produced an effect on the participants' Christian ethos that illuminated into tolerance, respect, and compassion for human kind. The participants embraced that ethos to thoughtfully engage in opportunities inside the classroom and within the college community to deepen their understandings of race, culture, and students of color. Thus, the richness of shared college experience at a liberal arts religious environment could have supported their racial identity development positively especially for Heather who reached disintegration status and Tiffany who reached pseudoindependence status. For these two preservice teachers, the racial identity statuses that were achieved were marked by openness to various perspectives that may also be related to religious beliefs reflecting similar qualities. ${ }^{35}$ Heather's racial identity statuses may have been affected by changes in spirituality, religious beliefs, or social implications of her faith such as to love your neighbor or to treat everyone equally. Moreover, Tiffany's racial identity was largely influenced by her religious upbringing that became a subset to her spiritual formation that deepened as a result of a missionary experience in Haiti transpiring an act for social justice and change for linguistically-diverse students. By having the courage and truth to question and explore the paradoxes inherent in their beliefs, Heather and Tiffany showed examples of their vocational calling 
capacity for connectedness on good teaching methods rooted in identity and the integrity. ${ }^{44}$ Undeniably, the relationship between racial identity development and religion that occurred for these preservice teachers allowed them to recognize their own misconceptions, advocate for contributions from people of color, and provide valuable learning opportunities for CLD students to achieve academic goals.

Finally, religious and family upbringing of all participants in the study largely attributed to how faith principles transferred into their lives. The intergenerational transmission of these practices and values were created from a cycle of activities relevant in the home involving discussions on religion, instruction of core ideas, prayer, and attendance in daily or weekly church activities, thus, allowing greater effects of role modeling from parents to the participants. ${ }^{59,60}$ Various scholars such as Lenski ${ }^{61}$ and Mahoney ${ }^{62}$ supported the role of religion in family functioning with linkages to how relationships and bonds are formed with the effects of religion on parenting and socialization processes. ${ }^{63}$ Parents' theological standards may have been associated to the practices that they instilled in their homes and the style or climate ${ }^{64}$ in how relationships were fostered. All participants specified close-knit bonds emphasized as part of their upbringing influenced by positive parent-child relationships that promoted facilitation of religious beliefs and values. Based on Bandura's social learning theory, ${ }^{65}$ participants in the study likely learned essential religious acts from their parents who practiced religion through childhood experiences involving observations and imitations that translated into behavioral attitudes in adolescence and early adult years.

\section{Conclusion}

This research study extended from previous studies to highlight benefits of embedding conversations about race and culture into teacher preparation programs with predominantly White candidates that currently exists in the United States ${ }^{5}$ as well as implications of Christian religious identity. ${ }^{46}$ Results indicated that preservice teachers' racial development initially fell at the lower level of Helm's ${ }^{28}$ theory; however, Christian environments can influence teachers' identities and understandings of race by prioritizing issues of race and diversity exemplified and shared from the context of the university's objectives, mission, and ethos. It may be appropriate to also infer benefits requiring faculty and staff members at religious-based institutions to integrate faith into teaching and learning. These religious and philosophical expectations can promote opportunities within classrooms and the wider college campus for students to engage in difficult discourses of race for predominantly White students. When religious implications provide a foundational core such as those found in participants' parental relationships and homes, preservice teachers may be less resistant to denying salient racial implications with their 
beliefs of CLD students. As such, faith-based institutions can provide safe learning spaces to dialogue, honor, question, and negotiate emotions or challenge negative perceptions in people of color. Positive benefits are best achieved when discourses of religion draw from multiple perspectives that extend beyond evangelical Christian worldviews given inherent ideologies of Whiteness. Empowering predominantly White preservice teachers through the integration of faith in teaching to engage and recognize their own consciousness can enact ways for them to comfortably address inequities of race to develop requisite strategies that serve all students effectively.

\section{Notes}

1. National Center for Education Statistics, the Condition of Education 2011 (Washington, DC: The United States Department of Education, 2011).

2. Gary Howard, We Can't Teach What We Don't Know: White Teacher, Multiracial Schools (New York, NY: Teachers College Press, 2006).

3. Karen Zumwalt and Elizabeth Craig, "Teachers' Characteristics: Research on the Demographic Profile." In Studying Teacher Education: The Report of the AERA Panel on Research and Teacher Education, edited by Marilyn Cochran-Smith and Kenneth Zeichner (Mahwah, NJ: Lawrence Erlbaum Associates, 2005), 111-56.

4. Geneva Gay and Tyrone Howard, "Multicultural Teacher Education for the 21st Century," Teacher Educator 36, no. 1 (2000): 1-16.

5. Linda Darling-Hammond and John Bransford, Preparing Teachers for a Changing World: What Teachers Should Learn and Be Able to Do (San Francisco, CA: Jossey Bass, 2005).

6. Shirley Heath, Ways with Words: Language, life, and Work in Communities and Classrooms (Cambridge, UK: Cambridge University Press, 1983).

7. Christine Sleeter and Charles Grant, "An Analysis of Multicultural Education in the United States," Harvard Educational Review 57, no. 4 (1987): 421-44.

8. Nora Hyland, "Being a Good Teacher of Black Students? White Teachers and Unintentional Racism," Curriculum Inquiry 35, no. 4 (2005): 429-59.

9. Geneva Gay, Culturally Responsive Teaching: Theory, Research, and Practice (New York, NY: Teachers College Press, 2000).

10. Wayne Au, Rethinking Multicultural Education: Teaching for Racial and Cultural Justice (Milwaukee, WI: Rethinking Schools, Ltd., 2009).

11. James Banks, "Race, Knowledge Construction, and Education in the United States: Lessons from History," in Handbook of Research on Multicultural Education, edited by J. Banks and C Banks (San Francisco: Jossey-Bass, 2004), 228-39.

12. Ana Villegas and Tamara Lucas, "Preparing Culturally Responsive Teachers: Rethinking the Curriculum," Journal of Teacher Education 53, no. 1 (2002): 20-32.

13. Patrick Solomona, John Portelli, Beverly-Jean Daniel, and Arlene Campbell, "The Discourse of Denial: How White Teacher Candidates Construct Race, Racism and 'White Privilege,' Race Ethnicity and Education 8, no. 2 (2005): 147-69.

14. Christine Bennett, Timothy Niggle, and Francis State, "Preservice Multicultural Education: Predictors of Student Readiness." Teaching and Teacher Education 8, no. 1 (1990): 243-54.

15. Ava McCall, "Constructing Conceptions of Multicultural Teaching: Preservice Teachers' Life Experiences and Teacher Education." Journal of Teacher Education 46, no. 5 (1995): 340-49. 
16. Sandra Lawrence and Beverly Tatum, "White Educators' Allies; Moving from Awareness to Action," in Off-white: Readings on Race, Power, and Society, edited by Michael Fine, Lois Weiss, Linda Powell, and M. Wong (New York: Routledge, 1997), 333-42.

17. Diane Bloom and Terri Peters, "Student Teaching Experience in Diverse Settings, White Racial Identity Development and Teacher Efficacy," Journal of Educational and Developmental Psychology 2, no. 2 (2012): 72-84.

18. Victoria Haviland, "Things Get Glossed Over: Rearticulating the Silencing Power of Whiteness in Education," Journal of Teacher Education 59, no. 40 (2008): 40-54.

19. Daniel Beverly Tatum, Why are All the Black Kids Sitting Together in the Cafeteria (New York, NY: Basic Books, 1997).

20. Tyrone Howard, Why Race and Culture Matter in Schools: Closing the Achievement Gap in America's Classrooms (New York, NY: Teachers College Press, 2010).

21. Frank Newport, Winning the White House: The Gallup Poll, Public Opinion, and the Presidency (New York, NY: Infobase Publishing, 2009).

22. Wei Gao and Gerald Mager, "Enhancing Preservice Teachers' Sense of Efficacy and Attitudes toward School Diversity through Preparation: A Case of One U.S. Inclusive Teacher Education Program," International Journal of Special Education 26, no. 2 (2011): 92-107.

23. Sonia Nieto, Affirming Diversity: The Sociopolitical Context of Multicultural Education (New York, NY: Longman, 2000).

24. Jacqueline Irvine, Educating Teachers for Diversity: Seeing with a Cultural Eye (New York, NY: Teachers College Press, 2003).

25. Gretchen McAllister and Jacqueline Irvine, "Cross Cultural Competency and Multicultural Teacher Education," Review of Educational Researcher 70, no 1 (2000): 3-24.

26. Christine Sleeter, Keepers of the American Dream: A Study of Staff Development and Multicultural Education (Washington, DC: The Falmer Press, 1992).

27. Nado Aveling, "Hacking at Our Very Roots: Rearticulating White Racial Identity within the Context of Teacher Education," Race Ethnicity and Education 9, no 3 (2006): 261-74.

28. Janet Helms, Black and White Racial Identity: Theory, Research, and Practice, ed. (Westport, CT: Greenwood Press, 1990).

29. Janet Helms, "An Update of Helm's White and People of Color Racial Identity Models," in Handbook of Multicultural Counseling, edited by J. G. Ponterotto, J. M. Casas, L. A. Suzuki, and C. M. Alexander (Thousand Oaks, CA: Sage, 1995), 181-91.

30. Janet Helms, "Challenging some Misuses of Reliability Coefficients as Reflected in Evaluation of the White Racial Identity Attitude Scale (WRIAS)," in Handbook of Racial-cultural Psychology and Counseling: Theory and Research, edited by R. T. Carter (New York, NY: Wiley, 2005), 360-90.

31. Elena Flores, Jeanna Tschann, Juanita Dimas, Lauri Pasch, and Cynthia de Groat, "Perceived Racial/Ethnic Discrimination, Posttraumatic Stress Symptoms, and Health Risk Behaviors among Mexican American Adolescents," Journal of Counseling Psychology 57, no. 3 (2010): 264-73.

32. Nancy Chick, Terri Karis, and Cyndi Kernahan, "Learning from their Own Learning. How Metacognitive and Meta-affective Reflections Enhance Learning in Race-Related Courses," International Journal for the Scholarship of Teaching and Learning 3 (2009): $1-28$.

33. Karen Fields, “On Emily Durkheim's The Elementary Forms of Religious Life: The Scholarly Translator's Work," The Journal of Historical Society 4, no. 2 (2004): 189-202.

34. Scott P. Richards and Allen Bergin, A Spiritual Strategy for Counseling and Psychotherapy (Washington, DC: American Psychological Association, 1997). 
35. Daniel Sciarra and George Gushue, "White Racial Identity Development and Religious Orientation," Journal of Counseling and Development 81 (2008): 473-82.

36. Gordon Allport, "The Religious Context of Prejudice," Journal of Scientific Study of Religion 5, No. 3 (1966): 447-57, 455.

37. Bob Altemeyer and Bruce Hunsberger, "Authoritarianism Religious Fundamentalism, Quest, and Prejudice," International Journal for the Psychology of Religion 2, no. 2 (1992): 113-33.

38. Daniel C. Batson, Patricia Schoenrade, and Larry W. Ventis, Religion and the Individual: A Social-Psychological Perspective (New York, NY: Oxford University Press, 1993).

39. Kevin Burke and Avner Segall, "Christianity and Its Legacy in Education," Journal of Curriculum Studies 43, no. 5 (2011): 631-58.

40. Paul Levesque and Andrea Guillaume, "Teachers, Evolution, and Religion: No Resolution in Sight," Review of Religious Education 51, no. 4 (2010): 349-65.

41. Mary Burke, Harold Hackey, Patricia Hudson, Judith Miranti, Gail Watts, and Lawrence Epp, "Spirituality, Religion and CACREP Curriculum Standards," Journal of Counseling and Development 77 (1999): 251-57.

42. Perry Glanzer and Nathan Alleman, "The Implications of Religious Identity for Teaching Ethics," Journal of Beliefs and Values 36, no. 2 (2015): 131-41.

43. Perry Glanzer and Tony Talbert, "The Impact and Implications of Faith or Worldview in the Classroom: The Priority and Importance of Character, Journal of Research in Character Education 3, no. 1 (2005): 25-42.

44. Parker Palmer, The Courage to Teach: Exploring the Inner Landscape of a Teacher's Life (San Francisco, CA: Jossey-Bass, 2007).

45. Dourne Macdonald and David Kirk, "Pedagogy, the Body and Christian Identity," Sport, Education and Society 4, no. 2 (1999): 131-42.

46. Kimberly White, "Connecting Religion and Teacher Identity: The Unexplored Relationship between Teachers and Religion in Public Schools," Teaching and Teacher Education 25, no. 6 (2009), 857-66.

47. Miles Kimball, Colter Mitchell, and Arland Thornton, "Empirics on the Origins of Preferences: The Case of College Major and Religiosity" (Working Paper No. 15182, National Bureau of Economic Research, 2009), http://www.nber.org/papers/w15182 (accessed December 1, 2015).

48. Clifford Mayes, Pamela Mayes, and Kay Sagmiller. "The Sense of Spiritual Calling among Teacher Education Students," Religion \& Education 30, no. 2 (2003): 84-109.

49. Deborah Fraser, "State Education, Spirituality, and Culture: Teachers' Personal and Professional Stories of Negotiating the Nexus," International Journal of Children's Spirituality 12, no. 3 (2007): 289-305.

50. Sang Lee, Ana Puig, Lauren Pasquarella-Daley, George Denny, Ann Rai, Aprille Dallape, and Parker Max Woodrow, "Revising the White Racial Consciousness Development Scale," Measurement and Evaluation in Counseling and Development 39, no. 4 (2007): 194-208.

51. John Creswell, Research Design: Qualitative, Quantitative, and Mixed Methods Approaches (Thousand Oaks, CA: Sage, 2003).

52. Cornel Pewewardy, "Shared Journaling: A Methodology for Engaging White Preservice Students into Multicultural Education Discourse," Teacher Education Quarterly 32, no. 1 (2005): 41-60.

53. Matthew Miles and Michael A. Huberman, Qualitative Data Analysis (Thousand Oaks, CA: Sage Publications, 1994).

54. Jean D. Clandinin and Michael F. Connelly, Narrative inquiry: Experience and Story in Qualitative Research (San Francisco, CA: Jossey-Bass, 2000). 
55. Mica Pollock, Sherry Deckman, Meredith Mira, and Carla Shalaby, "But What Can I Do? Three Necessary Tensions in Teaching Teachers about Race, Journal of Teacher Education 61, no. 3 (2010): 211-24.

56. Prentice Chandler, "Blinded by the White: Social Studies and Raceless Pedagogies," Journal of Educational Thought 43 (2009): 259-88.

57. Eduardo Bonilla-Silva. "The Linguistics of Color-blind Racism: How to Talk Nasty about Blacks Without Sounding "Racist"," Critical Sociology 41 (2002): 41-64.

58. Julie Horton and Dominic Scott, "White Students' Voices in Multicultural Teacher Education Preparation," Multicultural Education 11, no. 4 (2004): 2-16.

59. Joep Hart, "Impact of Religious Socialization in the Family," Journal of Empirical Theology 3, no. 1 (1990): 59-89.

60. Darren Sherkat, "Religious Socialization: Sources of Influence and Influences of Agency," in Handbook of the Sociology of Religion, edited by Michelle Dillon (Cambridge, UK: Cambridge University Press, 2003), 151-63.

61. Gerhard Lenski, The Religious Factor. A Sociological Study of Religion's Impact on Politics, Economics, and Family Life, rev. ed. (New York, NY: Doubleday Anchor Books, 1963).

62. Annette Mahoney, "Religion in Families, 1999-2009: A Relational Spirituality Framework," Journal of Marriage and Family 72, no. 4 (2010): 805-27.

63. Bruce Hunsberger and Laurence Brown, "Religious Socialization, Apostacy, and the Impact on Family Background," Journal for the Scientific Study of Religion 23, no. 3 (1984): 239-51.

64. Scott Myers, "An Interactive Model of Religiosity Inheritance: The Importance of Family Context," American Sociological Review 61, no. 5 (1996): 858-66.

65. Albert Bandura, Social Learning Theory (Morristown, NJ: General Learning Press, 1971). 